\title{
Sedentary Agriculture and Its Implications on Soil Quality in Agro-pastoral Semi-arid Karamoja, Uganda
}

\author{
S. Muwanga ${ }^{1,2}$, R. Onwonga ${ }^{2}$, S. O. Keya ${ }^{2} \&$ E. Komutunga ${ }^{3}$ \\ ${ }^{1}$ Nabuin Zonal Agricultural Research and Development Institute, National Agricultural Research Organisation, \\ Uganda \\ 2 Department of Land Resources Management and Agricultural Technology, College of Agriculture and \\ Veterinary Sciences, University of Nairobi, Kenya \\ ${ }^{3}$ National Agricultural Research Laboratories, National Agricultural Research Organisation, Uganda \\ Correspondence: S. Muwanga, Nabuin Zonal Agricultural Research and Development Institute, National \\ Agricultural Research Organisation, Uganda. E-mail: muwangantambi@gmail.com
}

Received: August 3, 2018

doi:10.5539/jas.v12n4p148
Accepted: January 31, $2020 \quad$ Online Published: March 15, 2020

URL: https://doi.org/10.5539/jas.v12n4p148

\begin{abstract}
Uganda Government embarked on promoting sedentary agriculture in Karamoja agro-pastoral semi-arid livelihood zone, which experience rapid environmental and high soil quality (SQ) decline. However, studies on sedentary agriculture's impact on soil quality using farmer's knowledge is limited. Consequently, a survey was carried out in Karamoja (Iriiri, Matany Sub-counties of Napak of districts and Rengen sub-county of Kotido) to determine the soil quality indicator parameters based on the farmers knowledge in order to build a local soil knowledge data base to better inform sustainable land use strategies. Using a semi-structured questionnaire, forty indigenous farmers per sub-county, were interviewed between August and September, 2015. The study took into account the social demographic characteristics of the people, farming enterprises, methods of crops production, crops yields trends, causes of the perceived yields trends and soil quality indicators. Prospects of developing Karamoja indigenous knowledge data base lies in visible feature that predict soil quality. Farmers used 36 parameters to determine SQ. The parameters were clustered into five categories; soil, crop, biological, environmental and management each category contributing to $42,19,14,8$ and $17 \%$ of the total indicators, respectively. The relationship between age group and the perceived indicators of soil fertility was statistically significant $(p$-value $=0.045)$ with the majority stating that they use either soil colour, soil depth or soil texture to express the fertility of soil. The farmer's soil quality indicators assessed in this study, is important in establishing indigenous-scientific hybrid knowledge data base to enhance soil fertility maintenance and better inform policy makers and other stakeholders on development of sustainable land use strategies.
\end{abstract}

Keywords: agro-pastoral, indigenous people, Karamoja, soil quality

\section{Introduction}

In the year 2010, the Government of Uganda embarked in an exercise to promote and extend sedentary agriculture to Karamoja pastoralists (MAAIF, 2010). This has resulted in conversion of expansive areas of the natural land cover into agriculture (Nakalembe et al., 2017). In the agro-pastoral zone the common crops grown which contribute $50 \%$ of household food and income include: sorghum (Sorghum bicolar L. Moench), maize (Zea mays L.), field peas (Vigna unguiculata L.) beans (Phaselous vulgaris L.), bulrush millet (Pennisetum glaucum L.), finger millet (Eleucine caracana L.), pigeon peas (Cajanus cajana L.) and sunflower (Helianthus annuus) (Jordaan, 2015). Unfortunately, in eastern Uganda crop yields are reportedly sub-optimal due to declining soil quality (Tenywa et al., 1999).

According to Ortega et al. (2016), sedentary agriculture are systems which started around year 12,000 BC, whereby groups of people and their animals started staying in one location permanently. Currently, such a system may include communal pastures where animals graze in proximity distances per day. The pastures are mainly natural rangelands and the cropping areas after harvesting or fallows. Sedentary agriculture is one of the coping strategies to enhance household food security. It can be somewhat brought about by changing economic 
activities, alteration in technologies, education and government policies. However, sedentary agriculture has a great influence on soil quality.

Soil quality, which is the ability of a soil to sustainably permit plant and animal productivity, conserve or augment water and air quality, and maintain people and their livelihood (Karlen et al.,1997), is generally on the decline throughout Sub-Saharan Africa. In respect of the declining soil quality due to land use alteration, farmers, scientists, policy makers and other stakeholders have become more concerned and have designed different mechanisms for detecting the changes (Muluneh \& Arnalds, 2011). Different stakeholders use different indicators to detect soil quality status at any point in time during farming (Buthelezi et al., 2013; Brandt \& Geeson, 2015).

Among several soil quality indicators which various studies have identified as fundamental for soil quality determination in sedentary agriculture is indigenous knowledge (Brandt \& Geeson, 2015). In line with it, farmers have designed copying strategies and/or mechanisms to ameliorate the deterioration. Although indigenous knowledge has no definite definition, it is important in solving local problems in poor communities. Investigating what the people know and have can enhance understanding of local conditions, thus providing productive context for strategies set to help the people (Werner, 2000).

Soil quality maintenance in Karamoja, like in most parts of Sub-Saharan Africa (SSA), is characterised by minimum addition of external inputs (Bekunda et al., 2002; Bekunda et al., 2010). For example, soil fertility is maintained through dry season grazing of the crop straws (adding livestock dung and urine) and by shifting cultivation. Livestock harvest forages, which they deposit in different parts of the farm as dung containing soil nutrients (Wells \& Dougherty, 1997).

In Uganda, a lot of research has been carried out in several locations on soil conservation practices as a part of soil quality maintenance (Bekunda et al., 2010). However, little has been done in Karamoja. This implies that, farmers have managed to keep the soil productive through inherited indigenous knowledge. Nonetheless, the farmers' knowledge of soil quality has been generally disregarded or undocumented by researchers (Mettrick, 1993). There is limited focus on indigenous' people and their complete wealth of knowledge on soil. Langill (1999) alerted researchers that the strength of indigenous knowledge lies in its ability to place local technologies in their socio-ecological settings. Elsewhere, it has been indicated clearly that the indigenous farmers have cocktails of knowledge to perceive differences in farming enterprise (Hart \& Mouton, 2005).

In order to maintain soil quality in its high productive state for a long time, it is imperative to integrate scientific knowledge of soil properties with other stakeholders' knowledge, for example, indigenous people's knowledge, that has sustainably allowed local communities to use and survive on the land (Shukla et al., 2006). The fact that farmers' indigenous knowledge, skills and experience on management of soil quality are not well documented in Karamoja, formed the basis of the current study. Perhaps, indigenous knowledge about soil quality alterations due to land use changes can be used to build a local soil knowledge data base to better inform land users. Hence, tapping, documenting and utilizing indigenous knowledge of Karamoja people before it is lost is crucial for practical design of soil quality conservation interventions in the agro-pastoral Karamoja.

\section{Materials and Methods}

\subsection{Site Description}

The study was carried out in Karamoja sub-region located about $340 \mathrm{~km} \mathrm{~N}$ E of Kampala the capital city of Uganda (Figure 1). The sub-region is made of Moroto, Nakapripirit, Amudat, Napak, Kotodo, Kabong and Abim districts. It lies between latitude $1^{\circ}-4^{\circ}$ North and longitudes $33^{\circ}-35^{\circ}$ East. Karamoja is mainly made up of three livelihood zones namely, agricultural, agro-pastoral and pastoral zones (Levine, 2010)]. Specifically, the study was carried out in agro-pastoral Kotido and Napak districts. The districts are located $03^{\circ} 31^{\prime} \mathrm{N}, 34^{\circ} 07^{\prime} \mathrm{E}$ and $02^{\circ} 12^{\prime} \mathrm{N}, 34^{\circ} 18^{\prime} \mathrm{E}$ respectively. Kotido has a population of 236,900 with a population density of $65.5 \mathrm{~km}^{-2}$. (UBOS, 2016). Napak population stands at 197,700 with population density of $39.7 \mathrm{~km}^{-2}$ (UBOS, 2016). One sub-county (Rengen) in Kotido and two (Iriri and Matany) in Napak districts were selected for the study. The sub-counties were selected because they were easily accessible and are representative of the agro-pastoral Karamoja. The area receives mono-model rainfall ranging between 500-760 minimum and 800-1000 mm maximum per year (Mubiru, 2010; Kyagulanyi et al., 2016). The average monthly minimum and maximum temperature ranges between $15-18^{\circ} \mathrm{C}$ and $28-32.4^{\circ} \mathrm{C}$, respectively (Mubiru, 2010). It has a very a potentially high evaporation rate, greater than the effective rainfall received (Kyagulanyi et al., 2016). The average wind speed is $12 \mathrm{~km}$ per hour with an estimated 10 hours of sunshine a day [hours when the sun is not obscured by clouds (Weather 2, 2018)]. 


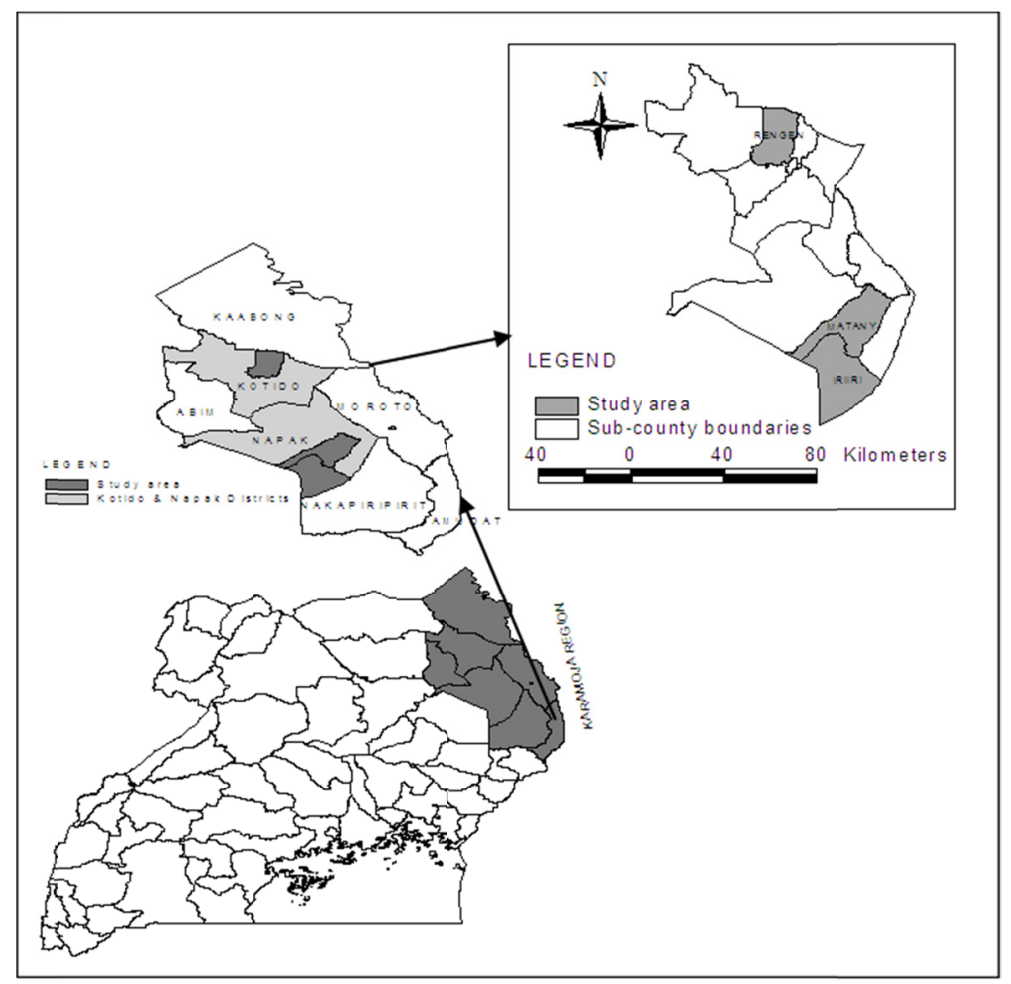

Figure 1. Map of Uganda showing Karamoja sub-region, the districts of Kotido and Napak and the study sub-counties of Iriiri, Matany and Rengen

\subsection{Data Collection}

A survey was carried out between August and September, 2015 in the agro-pastoral Karamoja in two districts of Kotido (Rengen sub-county) and Napak (Iriiri and Matany sub-counties) using a semi structured questionnaire. The study was purposively done to assess and determine soil quality indicators using sedentary indigenous farmers' knowledge.

To ensure quality of data collection, a team of enumerators from each study sub-county was selected and recruited with the help of the agricultural extension workers and sub-county chiefs. The teams were separately trained in all aspects concerning data collection. The training involved theoretical and practical aspects to ascertain that the enumerators were conversant with the questionnaire drawn to collect the desired data. The questionnaire was pretested in each study sub-counties to establish its clarity to both the enumerators and the respondents.

Survey sites and the respondents were selected purposively with the help of agricultural extension officers, political leaders and elders. Respondents were purposively selected targeting farm families which had been involved in farming for longer than ten years. The main purpose was to get experienced interviewee who were fit to represent the entire population of the agro-pastoral livelihood zone. Using the pretested semi-structured questionnaire, three face-to-face surveys were conducted in the sub-counties by the local enumerators who were earlier trained by the researcher.

The questionnaire which was used to assess farmers' indigenous perceptions on soil quality had closed and open-ended questions. Data on indigenous knowledge on soil quality, information about socio-demographic characteristics, crops yield trends and soil quality indicators were collected by individually interviewing a household member present. Forty farmers were interviewed from each of the three study sub-counties. In total, one hundred and twenty (120) farmers were interviewed from the entire study area. In addition, separate informal and interaction between the researchers, extension workers plus elders in the community were carried out and recorded to identify and document other indicators of soil quality which were not included in the questionnaire. For example the use of plants species as an indicator of soil quality.

\subsection{Statistical Data Analysis}

Data collected, was cleaned, coded and entered in the Statistical Package for Social Scientists (SPSS 24 version). 
Data analysis was done, where descriptive statistics were generated for each sub-county. The data collected from informal discussion with elders was analysed and presented as general indigenous knowledge for the entire study area.

\section{Results}

\subsection{Socio-demographic Characteristics of Respondents}

Most of the respondent were in their middle age throughout the study sub-counties followed by the old aged and a small number of youth (Table 1). As far as gender is concerned, more male in Iriiri and Rengen answered the questionnaire as opposed to the large number of female in Matany sub-county. Most of the interviewees were married in the study area. Divorced respondents and few singles were in Rengen and Iriiri with Matany registering neither. However, Matany had more widowed respondents followed by Rengen with Iriiri having none. Majority of the respondent were coming from families with 6-10 people. Respondent families varied from 1 to $>16$ and 1-10 people in Iriiri and Rengen sub-counties respectively. Majority of the respondents had received no formal education both in Iriiri and Rengen sub-county. All sub-counties had interviewees who had attended primary seven (P.7) formal education. Whereas no Rengen sub-county respondents had gone beyond P.7, Iriiri had all levels of education while Matany had more highly educated respondents than the rest of the study sub-counties.

Table 1. Socio-demographic characteristics of the respondents

\begin{tabular}{|c|c|c|c|c|}
\hline \multirow{2}{*}{ Demographics } & & \multicolumn{3}{|c|}{ Sub county\% respondents } \\
\hline & & Iriiri & Rengen & Matany \\
\hline \multirow{4}{*}{ Age group } & Youth (18-35) & 3.0 & 11.4 & 14.7 \\
\hline & Middle age(36-55) & 72.7 & 65.9 & 35.3 \\
\hline & Old $(55+)$ & 24.2 & 22.7 & 50.0 \\
\hline & $\mathbf{N}$ & 33 & 44 & 34 \\
\hline \multirow{3}{*}{ Gender } & Male & 57.6 & 56.8 & 14.7 \\
\hline & Female & 42.4 & 43.2 & 85.3 \\
\hline & $\mathbf{N}$ & 33 & 44 & 34 \\
\hline \multirow{5}{*}{ Marital status } & Married & 93.9 & 77.3 & 75.0 \\
\hline & Single & 3.0 & 11.4 & 0.0 \\
\hline & Divorced & 3.0 & 2.3 & 0.0 \\
\hline & Widowed & 0.0 & 9.1 & 25.0 \\
\hline & $\mathbf{N}$ & 33 & 44 & 32 \\
\hline \multirow{5}{*}{ Family size } & $1-5$ & 17.4 & 41.5 & 20.0 \\
\hline & $6-10$ & 39.1 & 43.9 & 80.0 \\
\hline & $11-15$ & 30.4 & 14.6 & 0.0 \\
\hline & $16+$ & 13.0 & 0.0 & 0.0 \\
\hline & $\mathbf{N}$ & 23 & 41 & 5 \\
\hline \multirow{7}{*}{ Highest level of education } & None & 69.7 & 0.0 & 94.1 \\
\hline & PLE (Primary Living examinations) P1-P7 & 12.1 & 47.2 & 5.9 \\
\hline & UCE(Secondary ordinary level) S1-S4 & 9.1 & 16.7 & 0.0 \\
\hline & UACE(Advanced level) S5-S6 & 3.0 & 2.8 & 0.0 \\
\hline & Tertiary education & 3.0 & 33.3 & 0.0 \\
\hline & Below PLE (Primary) & 3.0 & 0.0 & 0.0 \\
\hline & $\mathbf{N}$ & 33 & 36 & 34 \\
\hline
\end{tabular}

Note. $\mathrm{N}$ (in all Tables) is the number of respondents who answered the questions posed.

\subsection{Crops Commonly Grown in the Study Area}

Crops were grown throughout the study sub-counties. However, Rengen farmers were growing more crops than the rest, followed by Matany and lastly Iriiri. According to respondent perception, sorghum was the most widely 
grown crop throughout the study area, followed by maize, beans, sunflower, simsim and finger millet. A litany of other crops were reportedly grown (Table 2).

More beans, maize and sunflower were grown in Iriiri, than in Matany and Rengen sub-counties. Out of the three sub-counties Matany was by far the highest producer of cowpeas. Rengen sub-county exceeded the others in growing simsim, millet and groundnut (Table 2).

Table 2. Crops grown in each sub-county

\begin{tabular}{llll}
\hline \multirow{2}{*}{ Crop grown (\%) } & \multicolumn{3}{c}{ Sub county } \\
\cline { 2 - 4 } & Iriiri & Rengen & Matany \\
\hline Sorghum & $\mathbf{2 4 . 2 0}$ & $\mathbf{2 4 . 6 0}$ & $\mathbf{2 6 . 3 0}$ \\
Beans & $\mathbf{2 1 . 9 0}$ & $\mathbf{1 0 . 2 0}$ & $\mathbf{1 2 . 3 0}$ \\
Maize & $\mathbf{2 2 . 7 0}$ & $\mathbf{1 0 . 8 0}$ & $\mathbf{1 3 . 2 0}$ \\
Cowpeas & $\mathbf{2 . 3 0}$ & $\mathbf{3 . 6 0}$ & $\mathbf{1 3 . 2 0}$ \\
Simsim & $\mathbf{2 . 3 0}$ & $\mathbf{1 5 . 0 0}$ & $\mathbf{7 . 9 0}$ \\
Millets & 1.60 & 16.80 & 5.30 \\
Cucumber & 0.00 & 1.80 & 1.80 \\
Green grams & 3.10 & 0.00 & 2.60 \\
Pumpkins & 0.00 & 0.00 & 0.90 \\
Sunflower & 17.20 & 2.40 & 8.80 \\
Groundnut & 3.90 & 11.40 & 7.00 \\
Watermelon & 0.00 & 2.40 & 0.90 \\
Cabbages & 0.00 & 0.60 & 0.00 \\
Tomatoes & 0.00 & 0.60 & 0.00 \\
Pineapple & 0.80 & 0.00 & 0.00 \\
\hline N & $\mathbf{1 2 8}$ & $\mathbf{1 6 7}$ & $\mathbf{1 1 4}$ \\
\hline
\end{tabular}

\subsection{Farming Practices and Tools with Implications on Soil Quality}

The biggest number in the entire study area used hand hoes and /or slashers while farming, followed by those who used organic residues to amend their soil quality. Only a small number used chemicals. Interestingly, there were some famers who practiced irrigation (Table 3). All respondents in Matany agreed that they entirely use hand hoes/slasher for growing crops. Iriiri respondents mentioned that they used chemical fertilizers and irrigation for crop production. It was only in Rengen where it was mentioned that they used both farm and inorganic residues.

Table 3. Practices and tools used in raising crops on farm

\begin{tabular}{lllllll}
\hline \multirow{2}{*}{ Sub county } & \multicolumn{5}{c}{ Mode of raising crops (\%) } & \multirow{2}{*}{ N } \\
\cline { 2 - 6 } & Using hoes/slashers & Chemicals (pesticides) & Irrigating & Organic residues & House and inorganic fert & \\
\hline Iriiri & 76.90 & 5.10 & 17.90 & 0.00 & 0.00 & 39 \\
Rengen & 61.40 & 0.00 & 0.00 & 21.10 & 17.50 & 57 \\
Matany & 100.00 & 0.00 & 0.00 & 0.00 & 0.00 & 25 \\
\hline
\end{tabular}

\subsection{Crop Yield Trends}

According to farmers, the level of farm yield in the Karamoja region generally had been decreasing. Only $18.10 \%$ of the respondents mentioned that the yields were increasing. A small number of respondents were not aware of the trend of crop yield and did not respond to the locally known causes of yields decline (7.50\%). The decreasing crop yields trend could be attributed to soil exhaustion, changing weather and pests and disease.

\subsubsection{Causes of Crop Yield Decline}

The respondents who stated that farm yields were decreasing highlighted unfavourable climate, low quality of seeds, soil exhaustion, soil erosion, diseases and pests as major causes. Other reasons included lack of labour, inappropriate farming practices and illiteracy (Table 4). 
Table 4. Respondents assessment of causes of decreasing crop yields

\begin{tabular}{llll}
\hline \multirow{2}{*}{ Reasons for crop yield decrease (\%) } & \multicolumn{3}{c}{ Sub county } \\
\cline { 2 - 4 } & Iriiri & Rengen & Matany \\
\hline Unfavourable climate/ Unreliable rainfall & 8.20 & 21.43 & 46.97 \\
Lack of quality seeds for planting & 22.95 & 15.87 & 12.12 \\
Soil exhaustion & 18.03 & 17.46 & 9.09 \\
Soil erosion & 19.67 & 8.73 & 13.64 \\
Diseases (Crops infested with unknown diseases) and pests & 9.84 & 17.46 & 6.06 \\
Lack of labour to weed & 8.20 & 6.35 & 4.55 \\
Lack of fertilizer application both organic and inorganic & 13.11 & 0.79 & 0.00 \\
Poor farming methods & 0.00 & 3.17 & 3.03 \\
Poor tools & 0.00 & 2.38 & 3.03 \\
Livestock grazing in crops & 0.00 & 3.97 & 0.00 \\
Illiteracy & 0.00 & 0.79 & 1.52 \\
Lack of pesticides & 0.00 & 1.59 & 0.00 \\
N & 61 & 126 & 66 \\
\hline
\end{tabular}

\subsection{Farmers' General Perception on Soil Quality Trends}

Majority of the respondents from the entire study area (80.2\%) concurred that they understood the term soil quality through soil fertility. Nonetheless, a minority of interviewees (19.8\%) were not aware of soil quality. On the other hand, $73.60 \%$ of the respondents confessed, that the soil quality was declining and $26.4 \%$ were not aware of the changes.

\subsubsection{Farmer's Soil Quality Indicators}

Respondent farmers were able to tell of the decline in soil quality in Iriiri, Rengen and Matany using a combination of indicators (Table 5). The interviewee farmers indicated that they mainly use visual soil appraisal approach to identify their farm soil quality and determine its productivity. High and quality crop yields was perceived by the interviewees to be indicators of high quality soils for crop production and low crop yields for poor soils in all study sub-counties (Table 5).

Most farmers related loam soil to high quality as opposed to sand and clay. Soil black and brown colours were considered by respondents throughout the study area as more productive. Deep soil was perceived as soil more suitable for crop production.

A high quality soil was related to producing crops with strong stems (vigorous growing crops) whilst weak stems was related to low quality soils. Farmers further attributed low quality soils to the growth of certain weeds and other pests. Well drained soils were only mentioned in Rengen sub-county as indicator of high quality soils.

Soil with high humus content with the presence of earthworm was considered as high quality soil. Further, Matany respondent attributed high soil quality to moisture retention for a long time (without ponding) than the one which loses it. These responses from the interviewees could mean that they have experience that enables them to know the soil quality status. 
Table 5. Farmers' knowledge of good soil quality indicators

\begin{tabular}{llll}
\hline \multirow{2}{*}{ Farmers' indicators of high soil quality (\%) } & \multicolumn{3}{c}{ Sub county } \\
\cline { 2 - 4 } & Iriiri & Rengen & Matany \\
\hline High and quality crop yields & 41.03 & 14.48 & 20.00 \\
Soil texture and morphology (sandy, loam and clay) & 15.38 & 11.76 & 12.00 \\
Soil Colour (black, brown) & 7.69 & 12.67 & 12.00 \\
Soil depth (deep and shallow) & 7.69 & 8.60 & 14.00 \\
Crop firmness (strong and weak stems) & 8.97 & 6.33 & 22.00 \\
Presence of certain weeds and other pests & 5.13 & 8.60 & 10.00 \\
Natural vegetation (like tall grass) & 6.41 & 10.41 & 0.00 \\
Soil pH & 0.00 & 7.69 & 0.00 \\
Well drainage soil & 0.00 & 6.78 & 0.00 \\
Soil friability (easy to cultivate) & 6.41 & 0.45 & 10.00 \\
Soil structure & 0.00 & 2.71 & 0.00 \\
Soil degradation (visible erosion futures) & 0.00 & 3.61 & 0.00 \\
Humus content and macro-fauna presence & 1.28 & 4.06 & 0.00 \\
Good soil moisture retention & 0.00 & 1.81 & 0.00 \\
\hline N & $\mathbf{7 8}$ & $\mathbf{2 2 1}$ & $\mathbf{5 0}$ \\
\hline
\end{tabular}

\subsubsection{Farmers' Indicators of Declining Soil Quality}

Soil quality decline was assessed by respondent farmers using a cocktail of indicators (Table 6). In all study sub-counties, the major indicators of declining soil quality were low crop yields with deformed seeds, low harvest from the farm compared with previous harvests and crops growing poorly and maturing unevenly. Respondents in Iriiri and Rengen majorly assessed soil quality decline by the existence of certain weed species like witch weed (Striga species). Change of crop colour for instance from green to yellow was considered as an indicator of soil quality deterioration in Rengen and Matany. When soil which has been supporting high yielding crop previously, demonstrates poor seed germination and eventual stunted crop growth, farmers attributed this to reducing soil quality.

Table 6. Assessed declining soil quality indicators

\begin{tabular}{|c|c|c|c|}
\hline \multirow{2}{*}{ Soil quality decline indicators as perceived by the farmers } & \multicolumn{3}{|c|}{ Sub county } \\
\hline & Iriiri & Rengen & Matany \\
\hline Low quality yields (deformed and small seeds) & 41.94 & 17.57 & 61.76 \\
\hline Low harvests from the farm compared with the previous & 16.13 & 22.97 & 0.00 \\
\hline Crops growing poorly and maturing unevenly & 9.68 & 16.22 & 11.76 \\
\hline Existence of certain spp. of weeds (Lojokosimat, Kojosimat, Lokothima Bu, Akodet and striga) & 12.90 & 14.86 & 0.00 \\
\hline Highly eroded Soil & 6.45 & 8.11 & 8.82 \\
\hline Change in the colour of the crops (yellow) & 0.00 & 1.35 & 8.82 \\
\hline Previously Good demonstrate poor or no seed germination & 3.23 & 4.05 & 0.00 \\
\hline Stunted crops growth & 3.23 & 2.70 & 0.00 \\
\hline Crops wilt quickly soon after a rain season & 3.23 & 1.35 & 2.94 \\
\hline Crops with weak stems & 3.23 & 1.35 & 0.00 \\
\hline Development of hard pans (soil becomes difficult to work) & 0.00 & 2.70 & 0.00 \\
\hline Bare soil (becoming whitish with erosion features) & 0.00 & 2.70 & 0.00 \\
\hline Cracking soil & 0.00 & 1.35 & 2.94 \\
\hline Poor water infiltration through the soil (water ponding) & 0.00 & 1.35 & 2.94 \\
\hline Quick water drainage & 0.00 & 1.35 & 0.00 \\
\hline $\mathbf{N}$ & 31 & 74 & 34 \\
\hline
\end{tabular}

\subsubsection{Farmers' Use of Soil Texture as an Indicator of Soil Quality}

Soil texture as perceived by farmers (using feel method) Iriiri and Matany were mostly soft and fine, while that in Rengen were rough and less sticky. The different soil textures were perceived as soft and fine, rough, sandy or gritty, sticky and stony (Table 7). 
Soft and fine soils were perceived as good soil for crop cultivation, while rough textured soil was termed low to fairly good quality soils for farming. Sandy soils were perceived as poor for crop growth. Sticky soils were related to stagnant water and was of low value to crop cultivation. The shallow and stony soils were assessed as low quality soils for farming.

Table 7. Farmers' soil texture perception

\begin{tabular}{llllllll}
\hline \multirow{2}{*}{ Sub county } & \multicolumn{7}{c}{ Farmers Soil texture perception (\%) } \\
\cline { 2 - 7 } & Soft and fine & Rough & Sand soil & Sticky & Shallow & Stony & \\
\hline Iriiri & 22.2 & 27.8 & 1.9 & 40.7 & 0 & 7.4 & 54 \\
Rengen & 43.6 & 30.9 & 7.3 & 14.5 & 3.6 & 0 & 55 \\
Matany & 36.2 & 11.3 & 26.8 & 16.9 & 2.8 & 7 & 71 \\
\hline
\end{tabular}

\subsubsection{Farmers' Soil Suitability for Crop Production}

Using indigenous knowledge, Karamoja farmers classify soil quality for its suitability for agricultural use. The classification of soil and its suitability for use depended on the available plant species (Table 8). Farmers listed a number of plant species used as soil fertility indicators. They indicated the level of soil fertility and the main purpose for which the land under such indicators can be put to use (Table 8).

Table 8. Some common plant species used by Karamoja farmers as soil fertility indicators

\begin{tabular}{|c|c|c|}
\hline Soil status for crop production & $\begin{array}{l}\text { Indicator plant/weeds in } \\
\text { Ng'Karamojong language }\end{array}$ & $\begin{array}{l}\text { Economic importance of the weeds } \\
\text { mentioned by the farmers }\end{array}$ \\
\hline \multirow{4}{*}{ Fertile soil } & Ekwang (Abutilon hirtum) & \multirow{4}{*}{ Weeds pasture grass/legumes } \\
\hline & Emuria (Cynodon..dactylon) & \\
\hline & Eliaro (I kituiencis) & \\
\hline & Alilat & \\
\hline \multirow{5}{*}{ Poor soil (infertile soils) low productivity } & Lokile (Euphobia prostrate) & Good for grazing \\
\hline & Lomerekin (Biden pilosa) & Not good for grazing \\
\hline & Namareta/lochiktae & Retards crops growth \\
\hline & Emekui (Crossandra subacautis) & $\begin{array}{l}\text { Retards crop growth, bad for } \\
\text { grazing and injures farmers }\end{array}$ \\
\hline & Emoto (Striga hermonthica) & \\
\hline \multirow{9}{*}{$\begin{array}{l}\text { Fairly good soils (intermediate } \\
\text { between fertile and infertile soils) }\end{array}$} & - $\quad$ Grasses & \multirow{3}{*}{ Good grazing land } \\
\hline & Coach grass (Digitalia abbyssinica) & \\
\hline & Star grass (Cynodon dictyolon) & \\
\hline & Ereleng (Hyperrhania rufa) & \\
\hline & Nyemomya (Sorghum arundinacerum) & \\
\hline & Legumes & \\
\hline & Lomanang & \\
\hline & Edupanal (Hibiscus micrantha) & \\
\hline & Ekamongo & \\
\hline
\end{tabular}

Note. * Only or those mentioned/known to farmers.

\subsubsection{Farmers' Perception of Soil Taxonomy and Texture Related to Sorghum Yield}

Farmers had names for different soil texture and related it to sorghum yields (Table 9). Good quality soil was called Nyaro (Sandy loam by laboratory test) with the greatest expected sorghum yield. The Asinyon, the sand soils, were perceived as fairly good for crop cultivation. The Akapuyonait was perceived as good while Ekitera fairly good and Nyebur, low quality soil. This implied that texture and crop yields were highly important in determining soil name and quality among farmers. 
Table 9. Comparing farmers soil taxonomy and texture as related to perceived sorghum yields and measurable properties

\begin{tabular}{|c|c|c|c|c|c|}
\hline $\begin{array}{l}\text { Soil names } \\
\text { by farmers } \\
\text { (Taxonomy) }\end{array}$ & $\begin{array}{l}\text { Farmers' assessed } \\
\text { soil texture }\end{array}$ & $\begin{array}{l}\text { Perceived } \\
\text { Expected sorghum } \\
\text { crop yield\% }\end{array}$ & Frequency & Percentages & $\begin{array}{l}\text { Laboratory soil } \\
\text { physical property } \\
\text { (Textural class) }\end{array}$ \\
\hline Asinyon & Sandy (FGQ) & 50 & 22 & 19.3 & Sandy soil \\
\hline Nyaro. & Mixed (not well defined) (GQ) & 87 & 66 & 57.9 & Sandy loam \\
\hline Akapuyonait & Clay/loam GQ & 70 & 1 & 0.9 & Clay \\
\hline Elet. & (Fine clay) LQ & 50 & 5 & 4.4 & clay \\
\hline Nyebur & Rough texture LQ & 60 & 1 & 0.9 & Stony \\
\hline Ekitera & Slightly Sticky soil FQ & 45 & 15 & 13.2 & Sandy loam \\
\hline N & & & 110 & & \\
\hline
\end{tabular}

Note. GQ = good quality; FGQ = fairly good quality soil and LQ = low quality.

\subsubsection{Chi-square Differences in Demographic Characteristics Against Perceived Indicators of Soil}

The relationship between age group, family size and the perceived indicators of soil quality was statistically significant $(p$-value $=0.045)$; $(p$-value $=0.036)$, with the majority stating that they use either soil colour, soil depth or soil texture to tell the fertility of soil.

Specific factors were found to indicate the quality of soil, and it differed from age group to age group, While the youth (18-34 years) used soil colour and soil depth as indicators of soil quality, the middle aged (35-55 years) used soil colour and crop yield, and the old farmers used a wider variety of factors including: soil colour, soil texture, soil depth,. Crop firmness and crop yield.

\subsubsection{Summary of Farmer's Indicators of Soil Quality}

The indigenous farmers' knowledge about soil quality indicators is summarised in Table 10. The knowledge was categorised into five based on the source of the indicators listed by the farmers. Most of the indicators were soil based (42\%), followed by those related to crop management (17\%), and biologically based (14\%). 
Table 10. Summary of farmer's' indicators of soil quality

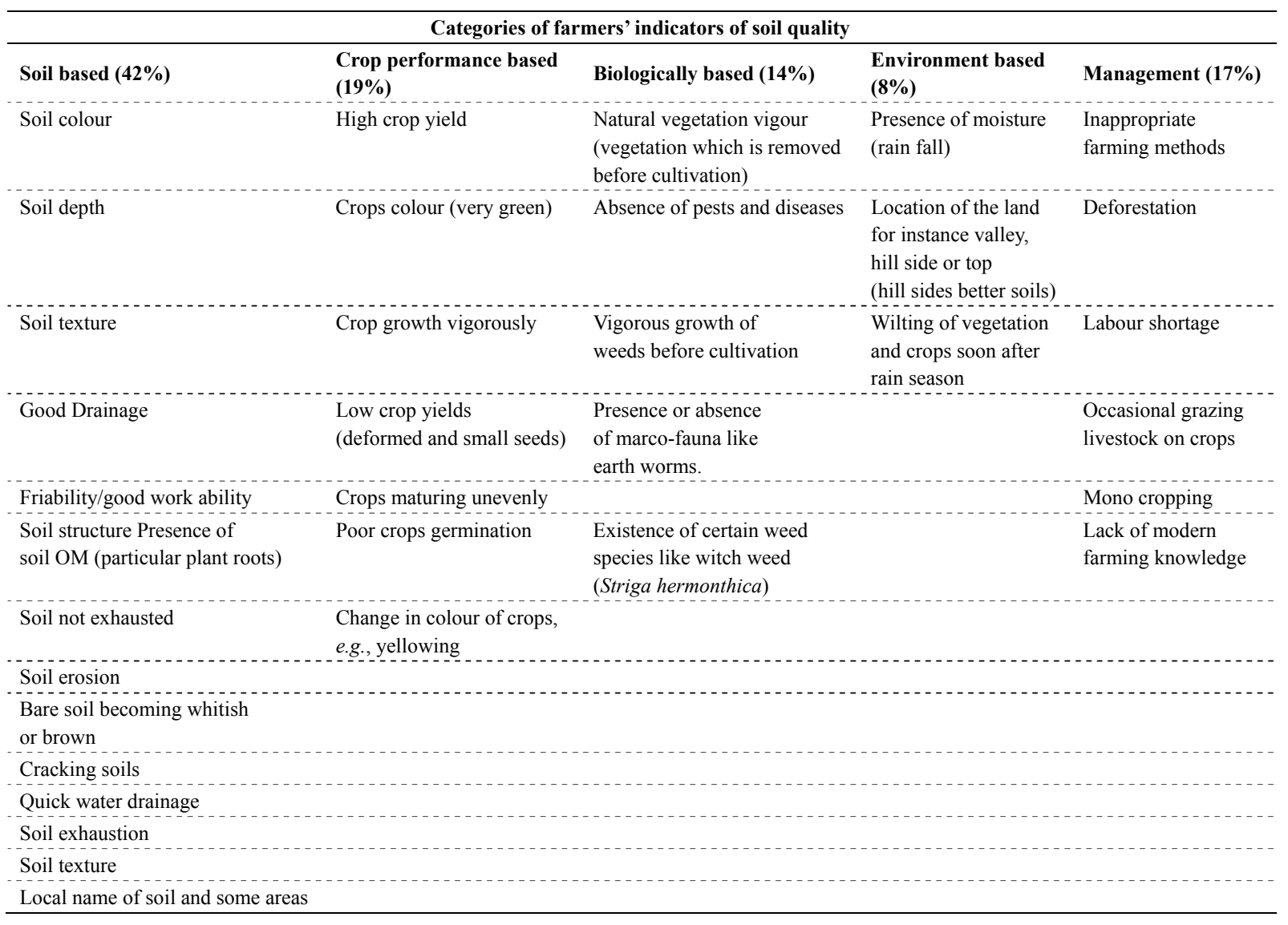

\section{Discussion}

\subsection{Socio-demographic Characteristics of Respondents}

The socio-economic and demographic characteristics in Iriiri Rengen and Matany sub-counties indicated that middle aged were more involved in sedentary farming than the old aged people and the young. This can be attributed to age difference, middle aged people tend to work a lot using both mental and physical capability to meet their increasing home demands. Old people tend to spend a lot of time on hobbies and leisure like drinking than the middle aged. Young people tend to spend a lot of time having fun with friends. In a study which was conducted by Verbrugge et al. (1996) in the Longitudinal Studies Branch, Gerontology Research Centre, National Institute on Aging, Baltimor, it was found out that different age groups allocate time for activities differently.

Mainly married people were involved in farming. This is expected in a population where children as young as 10 years of age get married. According to UBOS, 2017, 73.25\% of the people above 18 years in the study area are married and $50.5 \%$ are married at only 10 years of age.

It further illustrated that, farming is more dominated by men as opposed to the other gender. The male dominance in farming in the study area is because they are the household head in majority of the farm families [69 and 76\% in Napak and Kotido district respectively (UBOS, 2017)].

The study showed a low level of education in the community. Majority of the farmers were middle and old age with very low level of education $81.9 \%$ as opposed to the reported $80 \%$ for Napaka district or Bokora County. This is the basic level of education in Karamoja. Most of farmers in Karamojang (93\%) are involved in keeping cattle. Therefore, cattle is considered as a symbol of wealth and the noblest work (UBOS, 2017). As such, they preferred herding to attending schools. The mean farmers' household size for the study area (5-10) was in agreement with the reported 5.1 for Matany 5.4 for Iriiri and 7.0 for Rengen sub-counties (UBOS, 2017). 


\subsection{Crops Grown in the Study Area}

The reason for farmers' choice of growing sorghum and maize, than other crops could primarily be due to the fact that they are drought tolerant, versatile and meets farmers' need for both food and cash. This is in line with a study carried out by Kudadjie et al. (2004) and Murungweni (2016) which revealed sorghum and maize as climate smart crops. The second reason could be that the sorghum crop can store well under local conditions and the stems can be eaten like sugarcane by Karamoja local people. Therefore, it is preferred by most farmers. Thirdly, sorghum fetches high market price USD \$11-12 and \$16-23 compared to its supplementary maize crop, for which price ranges between $\$ 9-11$ and $\$ 14-22$ for a $100 \mathrm{~kg}$ bag during bumper harvest and bad seasons respectively (Ezaga, 2010). The growing of a variety of other crops in the study area was not a surprise. It is a common practice by most local farmers in various parts of Uganda, which helps to circumvent possible crop failure. This is in agreement with a study which was conducted in Zimbabwe by Makate et al. (2016), where crop diversification was used by farmers as a smart agricultural practice to enhance crop productivity and increase resilience in rural smallholders systems. Crop diversification can lead to reduced incidences of pests, diseases, and weed infestation (Larkin et al., 2010).

\subsection{Farming and Tools With Implications on Soil Quality}

The use of hand tools in the study area was expected in a community of poor farmers, who cannot afford the use of powered implements and can only buy rudimentary farm tools. The tools delay farm land preparation and other activities leading to late planting and plant growth which expose soil to erosion agent. This was in agreement with Levine (2010) whose report established and documented a cocktail of problems of farming in Karamoja. These included, but was not limited to, environmental degradation, deforestation, poor soils and use of rudimentary farm tools in cultivation. The use of chemical inputs (pesticides) and irrigation in Iriiri could be attributed to the fact that the sub-county shares its boundary with the relatively more advanced Teso Farming System where various pesticides and some irrigation are used in farming. Therefore, Iriiri farmers could have learnt modern farming practices by observation. In addition, Iriiri sub-county has a boarder trading centre market where some of these inputs could be sold.

\subsection{Crops Yields Trends}

The farmer's response to crop performance was not a surprise, because, most of the interviewed (farmers) had experienced many crop failures due to unreliable rainfall and prolonged dry spells. Further, the dry spell has both direct and the indirect effects. The direct is when crops dry due to insufficient moisture. The indirect can affect the quality of the yield. For instance when crops received less than enough rainfall, they may produce seeds which are not completely filled, leading to wrinkle and diseased seeds. In the subsequent season, farmers may plant these seeds and the resulting yield is likely to be lower than expected. In the study area, soil nutrient mining by crops (exhaustion) and erosion were perceived as the main causes of soil quality decline. These conclusions are similar to the ones recorded by Pimentel and Burgess (2013) and Hatfield et al. (2017), who cited high global soil loss through erosion ending up in declining crops yields worldwide. In addition, the reason for the crop yield decline could be that the soil fertility of Karamoja was low, so the first crops planted were likely to yield higher than the subsequent due to declining soil nutrient status without addition of external inputs. This is in line with a study by Tenywa et al. (1999) which was conducted on finger millet in eastern Uganda which revealed declining millet yields due to continuous cropping without additional external input.

\subsection{Causes of Crops Yields Decline}

The litany of other causes of decreasing crops yields perceived by indigenous people were expected and can be explained in part by farmers' having a good understanding of the causes of the crops yield decline. Firstly, this was in line with the GOU (2016), which warned that there was an increase in threat from the pests and diseases invasion. In particular, the Fall Army Worm (FAW) led to a 15\% loss of crop yield countrywide (GOU, 2016). Secondly, the crop yield decline is mainly attributed to unreliable rain season, dry spells and invasion by pests in particular the FAW (GOU, 2016). Thirdly, climatic change is reportedly influencing crop yields by increasing not only pest and diseases prevalence, but enhancing crop losses due to unpredictable weather patterns (Larkin et al., 2010; Makate et al., 2016). These directly reduce the planted crop population and yield per unit area. In a survey which was carried out by Nakalembe et al. (2017) in Moroto district, the farmers highlighted several causes of declining crop yield similar to the one mentioned by farmers in this study. 


\subsection{Farmers' General Perception on Soil Quality Trends}

Majority of the farmers understanding of the term soil quality and their awareness of its decline in quality was not a surprise, since most farmers' consider the soil fertility in relationship to the crop they wish to grow. The decision is mainly taken from the start when they clear the natural vegetation for farming. Farmers first judge whether the soil will produce a good crop or not. This is always done using observable features (Corbeels et al., 2000; Michel et al., 2015). The middle age and old age groups are usually the most knowledgeable age group in farming. They move a lot, compare their soil capability with others in their vicinity. They also discuss with fellow farmers, which makes it easy for them to know the soil quality or productivity status. They always use the experience they have gained over years of growing crops, to compare and contrast the soil productivity during the farm establishment and the existing status.

\subsection{Farmer' Perception of Soil Quality Indicators}

Perception of crops yields quality as indicator of soil quality by the farmers, revealed that they related output to the crops growing conditions. Normally, whatever reduces the quality of crops harvests decreases its palatability, saleability and profitability. This knowledge can be attributed to the high repeated agricultural activities done in the entire Rengen sub-county as oppose to other study sub-counties. Through repeated cultivation farmers might have acquired experience. It probable that, farmers using swift cultivation, have used different soil stypes for growing crops and through experience they have gained, can clearly tell the suitable soil physical conditions for crops growth. The indigenous knowledge recorded from the farmers, pointed out that their management systems are motivated by the yields prediction. Therefore, it is important to carry out small scale crops yields experiments with them to enhance their management skills. Highly eroded soil was only perceived as of low quality for crop cultivation in Matany. This is not a suprise as most highly eroded soils loose the quality for farming through erosion (Pimentel \& Burgess, 2013).

\subsection{Farmer's Indicators of Declining Soil Quality}

The indigenous knowledge of the Karamoja farmers was in agreement with the research finding recorded from Nicaragua dry forests. In the study, soil macro-fauna were the keys indicators of soil quality used by indigenous people (Pauli et al., 2016).

Soil moisture retention is important for plant growth. Soils which drain quickly leads to wilting of crops. On the other hand soils with ponding water are not suitable for crop production. Water ponding prevents soil aeration, a soil physical property which is important as a measurable soil quality indicator. The results were in agreement with the findings by Barrios et al. (1994), Fujisaka et al. (2000), Desbiez et al. (2003), and Fleskens and Jorritsma (2010), where farmers' indicators of soil quality were based on plant and/or crop growth, colour, water holding capacity and texture. However, Karamoja farmers added the term crop yield quality. It is well documented that nutrient deficiency in crops include necrosis, plants tissues death, loss of crops vigour, wilting. Reducing soil nutrient deficiencies reduces crop yields and plant yield quality. Similar responses were reported in a study which was conducted by Dawoe et al. (2012) in Ashanti region, Ghana. Scientifically, soil quality indicators are not only limited to its chemical, physical, biological properties but observations, socio-economic indicators together with the procedures used to measure these quantitative indices in agriculture in a broad sense (Mueller et al., 2010). In another, study was done by Fleskens and Jorritsma (2010) in Maroon soil fertility management in Suriname farmer's indicator of soil quality were crop growth, dark colour, water holding capacity and texture.

\subsection{Farmers Use of Texture as Indicator of Soil Quality}

Soil textural classes did not compare well with the analytical results from the National Agricultural Research Laboratories (NARL) Kawanda, which revealed that soil textural classes were; clay for Iriiri and Matany while Rengen soils were mainly sandy loam. In this regard, the soil texture determination by the farmers is not clear. The discrepancies between the scientific and the perceived soil texture can be attributed to the fact that farmer used very small areas to determine the texture, or that the samples they used were not representative enough. Therefore need further investigation.

\subsection{Farmer's Perception of Soil Suitability for Crops Production Using Natural Vegetation}

Naturally, plants prefer growing in places depending on the soil condition like $\mathrm{pH}$ and nutrients available concentration plus combinations. A soil which lack specific suitable soil nutrient and environment may not support some plant species growth. Therefore, plant propagation materials may be dispersed to a location but due to unfavourable conditions they fail to grow or are suppressed to allow only those which can survive. This in part, results into plants acting as observable indicators of soil quality. The recorded knowledge dates back in 1927, 
when Meinzer explained the existence plant species (xerophates) in deserts that either they use available water sparingly or deep root to trap water from lower water table for their survival.

\subsection{Chi-square Differences in Demographic Characteristics}

Information generated in the chi-squares test provide a realistic trend of indigenous knowledge in the study area. Different age groups use different indicators to determine soil quality. Old people have vast experience and wisdom to extend to the new generation both the inherited knowledge and those that they logically learnt from environmental situation. However, Herzog and Rodger (1988) have reported a result contrary to this that old people have poor knowledge.

\subsection{Summary of Farmer's Indicators of Soil Quality}

The indigenous knowledge categories predicts the importance of each source of information. The clusters are related to those which were mentioned by Desdiez et al. (2003). This indicated that Karamoja farmer's knowledge to a large extent is related to the measurable parameter. However, the main difference was that, farmers use mostly qualitative judgement to determine soil quality, whilst the scientific data which makes use of empirical data easy to quantify and compare. Farmer's use of the five summary categories parameters for determining soil quality are indicative of their importance and efforts must be given to see how they can be integrated as a measurable indicator of soil quality.

Generally, the study revealed that farmers in Karamoja use qualitative indices for soil quality as opposed to the quantitative indicators. The studies carried out by Desbiez et al. (2004), and Dawoe (2012) in Mid-hills of Nepal and Ashanti, Ghana respectively, found out that indicators similar to the one in this study were being used by farmers. Similarly, Habarurema and Steiner (1997) found out a corresponding relationship between farmers' of southern Rwanda soil classification to scientific soil suitability.

\section{Conclusion}

Karamoja agro-pastoral sedentary farmers' indigenous knowledge uses a cocktail of soil quality indicators. They have a vast knowledge of crops yields in relation to soil quality (SQ) terminologies which agree with scientific parameters. The major farmers' indicators of soil quality included; soil colour, soil morphology, soil depth, crop yields, plants growth vigour and colour, presence of certain weeds like Striga hermonthica (witch weed), presence or absence of macro-fauna like earthworms, rainfall, crops wilting during the offset of rain, inappropriate farming methods, labour shortage among others. These visible soil quality parameters could be summarized and assessed by farmers through five categories namely; soil, crops, biologically, environmentally and management based indicators.

According to farmers, soil quality is declining in the agro-pastoral semi-arid livelihood zone of Karamoja. Further, the study findings revealed that there is a need for the people of Karamoja to acquire formal education and on farm or field training. Therefore, it is imperative to carry out participatory small scale crops yields experiments with the farmers to enhance not only their management skills, but conserve soil quality and ensure sustainable land use.

\section{References}

Barrios, E., Herrera, R., \& Valles, J. L. (1994). Tropical floodplain agroforestry systems in mid-Orinoco River basin, Venezuela. Agrofor. Syst., 28, 143-157. https://doi.org/10.1007/BF00704826

Bekunda, M. A., Nkonya, E., Mugendi, D., \& Msaky, J. J. (2002). Soil fertility status, management, and research in East Africa. East African Journal of Rural Development, 20, 94-112. https://oi.org/10.4314/eajrd. v20i1.28362

Bekunda, M., Sanginga, N., \& Woomer, P. L. (2010). Restoring soil fertility in sub-Sahara Africa. Advances in Agronomy (Vol. 108, pp. 183-236). Academic Press. https://doi.org/10.1016/S0065-2113(10)08004-1

Brandt, J., \& Geeson, N. (2015). Desertification indicator system for Mediterranean Europe: Science, stakeholders and public dissemination of research results. Monitoring and Modelling Dynamic Environments (A Festschrift in Memory of Professor John B. Thornes, p. 121). https://doi.org/10.1002/ 9781118649596.ch6

Buthelezi, N. N., Hughes, J. C., \& Modi, A. T. (2013). The use of scientific and indigenous knowledge in agricultural land evaluation and soil fertility studies of two villages in KwaZulu-Natal, South Africa. African Journal of Agricultural Research, 8(6), 507-518. 
Corbeels, M., Shiferaw, A., \& Haile, M. (2000). Farmers' knowledge of soil fertility and local management strategies in Tigray, Ethiopia. IIED-Drylands Programme. Rome: United Nations Food and Agriculture Organization.

Dawoe, E. K., Quashie-Sam, J., Isaac, M. E., \& Oppong, S. K. (2012). Exploring farmers' local knowledge and perceptions of soil fertility and management in the Ashanti Region of Ghana. Geoderma, 179, 96-103. https://doi.org/10.1016/j.geoderma.2012.02.015

Desbiez, A., Matthews, R., Tripathi, B., \& Ellis-Jones, J. (2004). Perceptions and assessment of soil fertility by farmers in the mid-hills of Nepal. Agriculture, Ecosystems \& Environment, 103(1), 191-206. https://doi.org/10.1016/j.agee.2003.10.003

Ezaga, O. P. (2010). Markets for livestock and food crops in Karamoja subregion. Food Agric. Organ.

Fleskens, L., \& Jorritsma, F. (2010). A behavioural change perspective of Maroon soil fertility management in traditional shifting cultivation in Suriname. Human Ecology, 38(2), 217-236. https://oi.org/10.1007/ s10745-010-9307-5

Fujisaka, S., Escobar, G., \& Veneklaas, E. J. (2000). Weedy fields and forests: interactions between land use and the composition of plant communities in the Peruvian Amazon. Agric. Ecosyst. Environ., 78, $175-186$. https://doi.org/10.1016/S0167-8809(99)00122-X

GOU (Gorvenment of Uganda). (2016). Retrieved from http://gcic.gou.go.ug/press-release-army-worm

Habarurema, E., \& Steiner, K. G. (1997). Soil suitability classification by farmers in southern Rwanda. Geoderma, 75(1-2), 75-87. https://doi.org/10.1016/S0016-7061(96)00078-X

Hart, T., \& Mouton, J. (2005). Indigenous knowledge and its relevance for agriculture: A case study in Uganda. Indilinga African Journal of Indigenous Knowledge Systems, 4(1), 249-263.

Hatfield, J. L., Sauer, T. J., \& Cruse, R. M. (2017). Soil: The Forgotten Piece of the Water, Food, Energy Nexus. Advances in Agronomy (Vol. 143, pp. 1-46). Academic Press. https://doi.org/10.1016/bs.agron.2017.02.001

Herzog, A. R., \& Rodgers, W. L. (1988). Age and response rates to interview sample surveys. Journal of Gerontology, 43(6), S200-S205. https://doi.org/10.1093/geronj/43.6.S200

Jordaan, A. (2015). Karamoja, Uganda Drought Risk Assessment: Is drought to Blame for Chronic Food Insecurity? Retrieved from https://www.researchgate.net/publication/275887293_Karamoja_Uganda_ Drought_Risk_Assessment_Is_drought_to_Blame_for_Chronic_Food_Insecurity

Karlen, D. L., Mausbach, M. J., Doran, J. W., Cline, R. G., Harris, R. F., \& Schuman, G. E. (1997). Soil quality: A concept, definition, and framework for evaluation (a guest editorial). Soil Science Society of America Journal, 61(1), 4-10. https://doi.org/10.2136/sssaj1997.03615995006100010001x

Kudadjie, C. Y., Struik, P. C., Richards, P., \& Offei, S. K. (2004). Assessing production constraints, management and use of sorghum diversity in north-east Ghana: A diagnostic study. NJAS-Wageningen Journal of Life Sciences, 52(3-4), 371-391. https://doi.org/10.1016/S1573-5214(04)80022-8

Kyagulanyi, J., Kabenge, I., Banadda, N., Muyonga, J., Mulamba, P., \& Kiggundu, N. (2016). Estimation of spatial and temporal water requirements of grain amaranth using satellite, local and virtual weather stations datasets in Uganda. Journal Agric. and Bio Eng., 9(2). https://doi.org/10.365/j.ijabe.20160902.1676

Langill, S. (1999). Indigenous knowledge: A resource kit for sustainable development researchers in dryland Africa. People, Land and Water Program Initiative, International Development Research Centre, Ottawa, Ontario, Canada.

Larkin, R. P., Griffin, T. S., \& Honeycutt, C. W. (2010). Rotation and cover crop effects on soil borne potato diseases, tuber yield, and soil microbial communities. Plant Disease, 94(12), 1491-1502. https://doi.org/ 10.1094/PDIS-03-10-0172

Levine, S. (2010). What to do about Karamoja: Why pastoralism is not the problem but the solution. Food Security Analysis of Karamoja for FAO/ECHO.

MAAIF. (2010). MAAIF Statistical Abstract. Technical Report Ministry of Agriculture, Animal Industry and Fisheries, Uganda.

Makate, C., Wang, R., Makate, M., \& Mango, N. (2016). Crop diversification and livelihoods of smallholder farmers in Zimbabwe: Adaptive management for environmental change. SpringerPlus, 5(1), 1135. https://doi.org/10.1186/s40064-016-2802-4 
Meinzer, O. E. (1927). Plants as indicators of ground water (No. 577). US Govt. Print. Off.

Mettrick, H. (1993). Development oriented research in agriculture: An ICRA textbook. ICRA.

Michel, N. B. S., Monique, A. A., Lucien, B. N., \& Paul, B. (2015). Farmers' Perceptions of Soil Fertility Status in the Savannah Zone of Centre Cameroon. Journal of Agricultural Science and Technology A, 5(9), 723-731.

Mubiru. (2010). Climate change and adaptation options in Karamoja. Retrieved from http://www.fao.org/filead $\mathrm{min} /$ user-upload/drought/docs/1-Karamoja\%20Climate\%20Change\%20and\%20Adaptation\%20Options.pdf

Mueller, L., Schindler, U., Mirschel, W., Shepherd, T. G., Ball, B. C., Helming, K., ... Wiggering, H. (2010). Assessing the productivity function of soils: A review. Agronomy for Sustainable Development, 30(3), 601-614. https://doi.org/10.1051/agro/2009057

Muluneh, A., \& Arnalds, O. (2011). Synthesis of research on land use and land cover dynamics in the Ethiopian highlands. Geophysical Research Abstracts, 13, 1.

Murungweni, C., Van Wijk, M. T., Smaling, E. M. A., \& Giller, K. E. (2016). Climate-smart crop production in semi-arid areas through increased knowledge of varieties, environment and management factors. Nutrient Cycling in Agroecosystems, 105(3), 183-197. https://doi.org/10.1007/s10705-015-9695-4

Nakalembe, C., Dempewolf, J., \& Justice, C. (2017). Agricultural land use change in Karamoja Region, Uganda. Land Use Policy, 62, 2-12. https://doi.org/10.1016/j.landusepol.2016.11.029

Ortega Cobos, D., Ibá-ez, J. J., Campos, D., Khalidi, L., Méndez López, V., \& Teira, L. (2016). Systems of Interaction between the First Sedentary Villages in the Near East Exposed Using Agent-Based Modelling of Obsidian Exchange. Systems, 4(2), 18. https://doi.org/10.3390/systems4020018

Pauli, N., Abbott, L. K., Negrete-Yankelevich, S., \& Andrés, P. (2016). Farmers' knowledge and use of soil fauna in agriculture: A worldwide review. Ecology and Society, 21(3), 19. https://doi.org/10.5751/ES-08597210319

Pimentel, D., \& Burgess, M. (2013). Soil erosion threatens food production. Agriculture, 3(3), $443-463$. https://doi.org/10.3390/agriculture3030443

Shukla, M. K., Lai, R., \& Ebinger, M. (2006). Determining soil quality indicators by factor analysis. Soil Till. Res., 87, 194-204. https://doi.org/10.1016/j.still.2005.03.011

Tenywa, J. S., Nyende, P., Kidoido, M., Kasenge, V., Oryokot, J., \& Mbowa, S. (1999). Prospects and constraints of finger millet production in Eastern Uganda. African Crop Science Journal, 7(4), 569-583. https://doi.org/10.4314/acsj.v7i4.27751

Uganda Bureau of Statistics. (2017). The National Population and Housing Census 2014-Area Specific Profile Series. Kampala, Uganda. Retrieved from http://www.ubos.org

Verbrugge, L. M., Gruber-Baldini, A. L., \& Fozard, J. L. (1996). Age differences and age changes in activities: Baltimore Longitudinal Study of Aging. The Journals of Gerontology Series B: Psychological Sciences and Social Sciences, 51(1), S30-S41. https://doi.org/10.1093/geronb/51B.1.S30

Weather 2. (2018). Uganda Moroto climate. Retrieved from http://www.myweather2.com/City-Town/Uganda/ Moroto/climate-profile.aspx

Wells, K. L., \& Dougherty, C. T. (1997). Soil management for intensive grazing (Vol. 18, No. 2). Retrieved from http://www.uky.edu/Ag/Agronomy/Extension/ssnv/ssvl182.htm

Werner, P. (2000). Indigenous knowledge for development: A framework for action. Maseru: Centre for Resource and Environmental Studies, National University of Lesotho.

\section{Copyrights}

Copyright for this article is retained by the author(s), with first publication rights granted to the journal.

This is an open-access article distributed under the terms and conditions of the Creative Commons Attribution license (http://creativecommons.org/licenses/by/4.0/). 